\title{
As rasuras da modernidade na poesia de Sebastião Uchoa Leite
}

\author{
Paulo Andrade
}

Os entrecruzamentos de linguagens e as mesclas de territórios presentes na obra de Sebastião Uchoa Leite constituem, ao lado do uso consciente de clichês, da desconfiança do novo, do questionamento da originalidade e da autoria, marcas do universo pós-moderno, em cujo contexto circula o eu lírico da obra em questão. As relações de Uchoa Leite com o passado não são pautadas pelo desapreço ou pela agressividade. Ao contrário, o poeta utiliza a estratégia de apropriação da tradição, devorando linguagens e discursos disponíveis em seu contexto cultural.

O diálogo que Sebastião Uchoa Leite promove não só com as matrizes históricas, mas também com aquelas recalcadas pelo modernismo, como a cultura de massa, pode ser conferido também em outras vozes, como José Paulo Paes, em Meia palavra (1973), ou Silviano Santiago, em Crescendo durante a guerra numa província ultramarina (1978), que articula fragmentos da memória cultural com a memória pessoal do escritor, além de mapear diversos discursos, versões de fatos da política, citações, paródias, pastiches; ou, ainda, Armando Freitas Filho, em De cor (1988), que "redesenha o legado de nossa estética moderna e sinaliza os vínculos com seu próprio tempo"* Um bom

"(Pedrosa, Célia. "Poesia, lucidez e impasse". Jornal do Brasil, Caderno Idéias, exemplo desse diálogo é o poema "Ultima forma", de Armando 3 maio de 2003: 4). Freitas Filho:

Poe. Pound. Pós.

Baudelaire entra no ar como uma bandeira.

Somos esses passos

perdidos no deserto:

neste lugar-comum nenhum

em pedaços.

$[\cdots]$

Sumimos, sim

na sombra, no suor

e o boom do sol

$[\ldots]$ 
" (Freitas Filho, Armando. De cor. Rio de Janeiro: Nova Fronteira, 1988: 28).

" (Costa Lima, Luiz. "Se bastião Uchoa Leite em prosa e verso". Em: Inter venções. São Paulo: Edusp, 2002: 215-40).

\begin{abstract}
é a última ondalarme
que chega no espaço

no começo deste chão

em que vou cortando tudo

com uma faca cega.*
\end{abstract}

Ao mesmo tempo que o eu lírico incorpora a tradição moderna da poesia, ele se reconhece perdido por entre labirintos e fragmentos da história. Sobrevivente no universo contemporâneo, sentindo-se parte da "última ondalarme", o poeta segue um movimento errante recolhendo o que consegue cortar com sua “faca cega”, metáfora da falta de precisão com que o sujeito recorta fragmentos do contexto.

Vale conferir o comentário que Uchoa Leite faz da poesia de Armando Freitas Filho, seu companheiro de viagem, na orelha do livro citado:

Citações, alusões, colagem de segmentos, bric-à-brac da poesia e da vida cotidiana, "melange adultere de tout", conforme Corbiére. Estamos diante de um vale tudo. Clichês verbais, marcas registradas, descabelamentos bufônicos, trocadilhos nonsense, metáforas do technicolor e do branco-e-preto etc. Certo sabor de mass media confundido com um à la recherche da poesia perdida nos refugos urbanos.

O comentário de Uchoa Leite aplica-se mais a sua própria práxis poética do que à de Armando Freitas Filho, sendo válido afirmar que as questões analíticas do crítico auxiliam a esclarecer a poética que produz, fazendo da sua produção crítica um "suplemento interpretativo", como observa Costa Lima.*

Conscientes de que, no universo contemporâneo, a comunicação de massa é peça indissociável da arte, os artistas incorporam e põem em circulação bens culturais de toda a ordem, sem deixar de serem críticos à realidade da indústria cultural. Nem apocalípticos, nem integrados, esses artistas sabem que muitos valores são fornecidos e construídos pelos veículos de massa e reproduzidos pelas novas formas de comunicação.

Além da incorporação de elementos gerados e difundidos pela indústria cultural, a revisitação do passado foi outra tática encontrada para enfrentar o peso da tradição moderna que condiciona e, de certa maneira, oprime o artista contemporâneo.

$\mathrm{Na}$ literatura brasileira, Silviano Santiago é modelo de intelectual que procura saídas para se libertar do peso da 
tradição modernista. Uma experiência material desse recurso encontra-se na prosa Em liberdade (1981), livro em que o crítico reconstitui um falso diário, supostamente escrito por Graciliano Ramos, que daria continuidade a Memórias do cárcere. Ao mesmo tempo que fala de Graciliano Ramos, o livro projetase no passado remoto e recria figuras como Cláudio Manuel da Costa e Wladimir Herzog, estabelecendo um paralelo entre as dificuldades vividas pelos intelectuais e artistas em três momentos diferentes. Em entrevista, Santiago reflete sobre como os artistas têm buscado formas de se libertar do peso da tradição e sobre as relações do escritor contemporâneo com seus antecessores:

Um dos problemas básicos da minha geração - e quando falo da minha geração seriam os escritores que têm, hoje, por volta dos cinqüenta anos - foi a alta carga de motivação, de força artística, moral, ética e estética que recebemos da geração modernista. É impossível, para nós, não nos darmos conta de que lemos, nos educamos e amadurecemos a partir dos grandes autores modernistas: Mário de Andrade, Oswald de Andrade, Graciliano Ramos, Clarice Lispector, Guimarães Rosa etc. Isso se tornou um peso enorme para todos nós. E este peso nos leva a uma reação. Não a uma reação vanguardista do ano de 1922, sair em busca de uma espécie de marco zero. Não é possível dizer que nada houve, ou que o que havia antes não valia a pena, e por isso tentar atualizar com as novas vanguardas européias. Havia realmente alguma coisa de forte antes - que eu reverencio e merece a minha melhor opinião.

A postura de Silviano Santiago não é a de rechaçar o passado, tal como fizeram as vanguardas que se afirmavam pela negação da tradição. Se a paródia de escárnio e desapreço fora um recurso eficaz para menosprezar a tradição no princípio do século XX, tal fórmula não tem eficácia para os escritores da geração de Sebastião Uchoa Leite, Armando Freitas Filho, José Paulo Paes e o próprio Santiago:

a minha geração [...] trata da tradição modernista, e com maior prazer. Leio e releio Mário, Oswald, Drummond [...]. Nesse sentido, a reação à tradição não pode ser mais a paródia, mas também ela não pode ser só reverência, senão não existo, nós não existimos. Era preciso buscar uma maneira de trabalhar as brechas do Modernismo. Suas lacunas. Certos tabus. E de trabalhar os medos e, até mesmo, as insuficiências modernistas.*
" (Santiago, Silviano. "No corpo da escrita". Su. plemento Literário. Belo Horizonte, 3 agosto de 1991: 2-4). 
A astúcia de infiltrar-se na tradição pelas frestas, preenchendo as lacunas do modernismo, constitui uma das principais estratégias de produção do artista contemporâneo e configura um modo de pensar determinadas questões estéticas e ideológicas a contrapelo domodernismo:

Como artista, devo afirmar que o Modernismo já tem setenta anos. E não vejo sentido em dar continuidade a um movimento que está fazendo setenta anos de idade. O Modernismo, para mim, é tradição, e eu reverencio. Mas a tradição não é uma força. O Modernismo, para mim, é uma forma e não mais uma força.*

O desgaste causado pela busca do novo no decorrer da primeira metade do século XX fez com que a poesia brasileira contemporânea questionasse se, após a herança deixada por movimentos como o modernismo de 1922 e as vanguardas pós-50, ainda haveria a mesma demanda de atualização estética da literatura nacional.

O hibridismo de recursos advindos de origem e linguagens diversas foi uma saída para os poetas e artistas que optaram pela não continuidade ao discurso da ruptura. A revisitação e as referências às diversas áreas da cultura fizeram surgir uma pluralidade de vozes que presentificam, na poesia, ruínas do passado. A essa reciclagem de dicções, modernas ou não, e a utilização de variados recursos poéticos, que configuram o quadro da poesia contemporânea, Benedito Nunes denomina "esfolhamento das tradições":

a conversão de cânones, esvaziados de sua função normativa, em fontes livremente disponíveis com as quais incessantemente dialogam os poetas. Depara-se-nos a convergência, o entrecruzamento dos múltiplos caminhos por eles percorridos, que são outros textos, de tempos e espaços diferentes, na cena literária móvel do presente dentro da biblioteca de babel da nossa cultura.*

Os recursos que compõem o perfil híbrido da produção poética dos anos 1980 já estavam presentes em autores modernistas, tais como a "tematização reflexiva da poesia”, "a técnica do fragmento, o estilo neo-retórico, e a configuração epigramática”* . No entanto, ao serem reativados, tais traços são reescritos, deslocando seus contextos, por meio de novas leituras interpretativas. Lacunas insurgem de modo crítico sobre textos e valores canônicos. Um bom exemplo é o poema "Variação sobre Ricardo Reis”, que Sebastião Uchoa Leite publicou em $A$ regra secreta: 
O poema mantém a simetria nos cortes, na forma, mas o eu lírico, ao se inserir no texto, inverte o sentido do discurso, expondo as lacunas do racionalismo cultuado pelo heterônimo de Fernando Pessoa. A fragmentação, que foi um dos principais recursos modernistas para gerar significados que remetem ao universo fraturado do sujeito lírico, ganha novas conotações ao consolidar a suspeita radical do poeta diante da própria possibilidade de qualquer consciência racional acerca do universo.

Em muitos poemas de Uchoa Leite, esse entrecruzamento de linguagens acaba por desvelar o jogo literário, trazendo à tona seu processo de criação, pelo qual o texto poético é construído com resíduos e recalques da tradição.

A deglutição crítica realizada por Sebastião Uchoa Leite, ao aproveitar matrizes da cultura nacional e estrangeira e de várias linguagens artísticas, faz ressurgir um ritual antropofágico, corroendo o outro e absorvendo-o para si. Essa retomada, no entanto, não quer dizer uma reedição do movimento de 1928. Oswald de Andrade mergulhou nas fontes primitivas do não-civilizado, para recuperar elementos de culturas recalcadas e fazer uma crítica à cultura européia, mas essa busca de originalidade, por meio de uma erradicação do passadismo, não integra a pauta dos artistas contemporâneos.

Ao rejeitar a idéia de destruição e de recomeço num grau zero da cultura, o poeta utiliza a estratégia de apropriação da tradição, devorando a linguagem do outro com sua "fome de corrosão", como assume o sujeito lírico no poema "Gênero vitríolo”, de Antilogia: 
" (Leite. Sebastião Uchoa. Obras em dobras (1960. 1988). São Paulo: Duas Cidades, 1988: 133).
" (citado por Compagnon, Antoine. Os cinco paradoxos da modernidade. Belo Horizonte: Ed. UFMG, 1999: 118).

\author{
do outro lado é o meu não-corpo \\ uns tomam éter outros vitríolo \\ eu bebo o possível \\ bebo os mordentes \\ sou todo intestino \\ com fome de corrosão \\ bebo o anti-leite \\ com gosto de anti-matéria \\ salto para o lado do meu outro \\ aperto a mão \\ do anti-sebastião u leite \\ e explodo. *
}

Atuando como catalisador de linguagens, sua intenção é incorporar o outro, afinal ele bebe o possível, pois é "todo intestino”. Ao se apropriar de elementos díspares, sem negar o distinto de si, o poeta adere à multiplicidade na busca do seu duplo (“salto para o lado do meu outro"). Consciente de que o conhecimento de si é necessariamente intermediado pela interrelação com o outro, declara: "aperto a mão/ do anti-sebastião u leite/ e explodo”. Ao explodir, espalha fragmentos de si já contaminados por algo diferente dele, da cultura e da tradição, e elabora textos em constelação.

\section{Rasuras da modernidade}

A obra de Sebastião Uchoa Leite é produtiva para a reflexão dos significados que o uso de clichês e a desconfiança em relação ao novo atingem no contexto de sua produção. Enquanto o artista moderno explora conotações heróicas, na expressão de sua subjetividade, buscando atingir a destruição do velho e a instauração do novo, o pós-modernismo pode ser definido como a impossibilidade de se posicionar como criador, seja de novas formas de expressão, seja de novas formas de vida social. O que torna compreensível a crítica de Greenberg, numa conferência de 1980, em que define o pós-modernismo como "uma demissão, a renúncia ao heroísmo e ao purismo moderno”* .

A poesia de Uchoa Leite está inserida numa questão, cujo ponto central é a distinção entre a cultura contemporânea e as realizações do alto modernismo e da vanguarda; uma problemática que tem suas raízes nas experiências e articulações dos anos 1960 e 1970 . Uma poética que revela que os padrões de pensamento e de ação da modernidade perdiam a força. Não por 
acaso, temas como a crise das utopias e o ocaso das vanguardas se encontram dramatizados em sua poesia.

Ao descartar os discursos heróicos dos modernistas, o eu lírico evita ser portador de causas ou ideologias que alimentem esperanças num futuro otimista para o homem. A utopia do progresso, que promete ao homem moderno o sonho do paraíso terrestre, passa a ser questionada e desacreditada na Europa como conseqüência do desmascaramento de suas contradições internas, explicitadas ao longo das duas guerras mundiais. O desenvolvimento tecnológico deixa de ser a mola que impulsiona o progresso e passa a ser visto como algo que pode pôr em risco a própria humanidade. De tanto negar a si mesmo, o projeto da modernidade entra em crise e expõe as fissuras na sua construção interna.

Os níveis de transgressão propostos pela arte das vanguardas, portanto, começam a se deparar com limites. A lógica da revolução permanente devora a si mesma. Sem encontrar mais caminhos para onde ir após ter utilizado todo o repertório de choques e escândalos possíveis, as vanguardas sofrem, como observa Umberto Eco, um processo autofágico:

a vanguarda [...] destrói a figura e, em seguida, a anula, chegando ao abstrato, ao informal, à tela branca, à tela rasgada, à tela queimada; [...] em literatura, será a destruição do fluxo do discurso, até à colagem à maneira de Bourroughs, até ao silêncio ou à página em branco; em música, será a passagem da atonalidade ao ruído, ao silêncio absoluto.*

A iconoclastia da arte moderna perde sua capacidade de transgredir os valores burgueses para ser interpretada como reflexo do próprio sistema capitalista, ou seja, instala-se, entre os artistas, a suspeita diante da separação entre a modernidade estética e a modernidade burguesa, que, segundo Calinescu, foi a espinha dorsal da literatura moderna, fundada, sobretudo, por Baudelaire. A obra de Baudelaire representa o momento em que a arte se configura como dupla negação, ou seja, como ruptura em relação aos valores estéticos da tradição e aos valores da civilização burguesa.

Cresce também nesse período a idéia de que a rebeldia da arte moderna havia se convertido em procedimento vazio, espécie de repetição ritual em que a crítica se transforma em retórica e a transgressão, em cerimônia. A idéia de uma sucessão progressiva de movimentos é substituída pela convivência de
" (Eco, Umberto. Pós-escrito a $\mathrm{O}$ nome da Rosa. Rio de Janeiro: Nova Fronteira, 1985: 56). 
" (Compagnon, Antoine. Os cinco paradoxos da mo dernidade. Ob. cit.: 125).

" (Lyotard, Jean-François. O pós-moderno explicado às crianças. Lisboa: Dom Quixote, 1993: 24). tendências díspares, gerando a pluralidade e o hibridismo de formas e procedimentos artísticos. As novas invenções artísticas não se destinam a afugentar as existentes e lhes tomar o lugar, mas a se juntar às outras, procurando algum espaço para se moverem, por si próprias, no palco artístico notoriamente superlotado.

Desse modo, a visão diacrônica perde terreno para o sincrônico, uma vez que o cotidiano, nossas experiências psíquicas, nossas linguagens culturais são hoje dominadas pelas categorias de espaço e não pelas de tempo. A crença numa crise da historicidade e no domínio de uma cultura cada vez mais dominada pela lógica espacial, como se vivêssemos num presente perpétuo, em que se perdeu a consciência da sucessão dos fatos e se passou a enfatizar a co-presença, é um dos principais fenômenos apontados pelos que analisam a sociedade contemporânea.

A rasura na mentalidade da ruptura gera uma estética de fechamento, como diria Antoine Compagnon: "da ruptura com a tradição à tradição da ruptura e, por fim, à ruptura com a ruptura, que seria a nossa pós-modernidade"*.

Não faz parte do pensamento pós-moderno a pretensão de suplantar o moderno; ao contrário, o pós-moderno trabalha no próprio interior da modernidade, em negociação constante com seu discurso, o que equivale a dizer que ele é intrínseco ao moderno, sendo, portanto, um estágio recorrente no interior do modernismo, como ensina Lyotard.*

Esse redimensionamento de pensamento e de procedimentos técnicos e estilísticos, que afasta dos artistas contemporâneos a noção de inovação e ruptura, orienta o fazer literário de Sebastião Uchoa Leite, que se constrói nas ruínas da tradição, enfrentando o desgaste de formas e clichês poéticos. O diálogo intertextual que faz aflorar muito do que foi recalcado pela tradição é uma das principais estratégias de construção de sentidos poéticos na obra desse poeta. A esta altura, importa focalizar as diferentes relações que o modernismo e o pós-modernismo mantêm com a cultura de massa, e outros valores dicotômicos de avaliação dos bens culturais.

\section{Cultura de massa: o outro}

Muitas teorias sobre a arte pós-moderna surgiram como reação às formulações de Clement Greenberg, influente teórico de arte que legitimou a teoria do modernismo nas artes plásticas. Considerado 
um dos grandes pensadores da arte modernista, Greenberg é o defensor da última trincheira de pureza e singularidade da estética modernista. Desde o início dos anos 1940, é considerado inimigo implacável da cultura de massa e defensor da barreira, assumida como necessária e intransponível, que separava a cultura elevada e a cultura de massa nas sociedades capitalistas modernas.

Em Arte e cultura, Greenberg insiste na autonomia estética e defende que a pintura deveria, em sua especificidade, delimitar seu campo de atividade, distanciando-se de tudo que compartilha com as outras artes, a exemplo do figurativo, que vem da literatura. Uma obra de arte moderna, defende Greenberg, deve evitar a dependência de qualquer ordem de experiência que não seja dada "pela natureza mais essencialmente construída de seu meio”. Isso quer dizer que as artes devem atingir a concretude, a "pureza, agindo exclusivamente nos termos de suas individualidades separadas e irredutíveis”* A pintura abstrata seria um exemplo bem-sucedido dessa busca pela especificidade e pureza da arte, sendo inequívoco que, na busca da especialização da arte, subjaz a separação categórica entre a alta cultura e a cultura de massa.

Tanto a força quanto a fraqueza do modernismo como cultura de oposição derivam da estratégia consciente de não se deixar contaminar pela cultura de massa: "o outro do modernismo”, “o espectro que o assombra, a ameaça contra a qual a alta arte tem de demarcar seu terreno"*

A busca obstinada pela especificidade da linguagem artística resulta dessa luta contra os perigos da contaminação da arte pelos bens culturais, afinal a autonomia da obra de arte modernista é resultado de uma resistência à tentação sedutora da cultura de massa. As fronteiras estabelecidas entre alta arte e cultura de massa, todavia, foram sendo cada vez mais postas em xeque pela imbricação entre as linguagens do cinema, da literatura, da arquitetura. Com efeito, uma das questões centrais no debate sobre o pós-modernismo é enfrentar o desmoronamento do muro que separava a arte da cultura de massa, com base na crítica aguda ao cânone do alto modernismo, formulada pelos movimentos artísticos dos anos 1960.

\section{Contaminações e hesitações}

Ao mesmo tempo que Uchoa Leite preserva as premissas da arte modernista, sua poesia se distancia delas, buscando conscientemente uma contaminação com outras linguagens. Do mesmo
" (Greenberg, Clement. Arte e cultura: ensaios críticos (1961). São Paulo: Ática, 2001: 150).

" (Huyssen, Andreas. Me mórias do modernismo. Rio de Janeiro: Ed. UFRJ, 1997: 57). 
modo que a obra de arte modernista busca autonomia em sua separação da cultura de massa, a obra de Sebastião procura autonomizar-se em sua liberdade de trânsito pela realidade contemporânea, santuário do consumo.

O poeta elabora uma linguagem construída pelo entrecruzamento de discursos e idiomas, em que rearranja e recombina peças que possibilitam uma proliferação inusitada de sentidos. A desorientação é efetivamente o seu "Antimétodo" de composição:

Desoriento-me

Sem qualquer

Método

Ou sem

Qualquer fim

Vou e não vou

Mas vou

Caio sem qualquer

Alarde

O que é

E não é: mas é

Desorientar-me

É meu antimétodo*

O perigo de ser devorada pela cultura de massa, por meio da cooptação e do mercantilismo - tipo indesejável de sucesso -, é o medo constante da arte modernista, que tenta demarcar seu território fortificando as fronteiras entre a arte "genuína" e seu outro. A obstinada impureza do discurso poético, paradoxalmente, afasta a poesia de Uchoa Leite da literatura de massa, por lhe conferir alto grau de dificuldade de absorção pelo leitor, que estranha (na concepção de Chklovski) o embaralhamento de linguagens.

A poesia de Uchoa Leite funciona como uma resistência da palavra, pelo grau de dificuldade que sua leitura impõe ao leitor e pela complexidade dos deslocamentos associativos operados nos versos, cujas fontes são difíceis de serem encontradas pelo analista. Seu trabalho, portanto, está longe de conviver com a ameaça de cooptação e das tentações do mercado ou por regras sociais de comportamento literário.

Mais que um exibicionismo de referências, os personagens que figuram em seus poemas possuem significações específicas dentro de sua poética. As alusões a Mallarmé, Valéry, Pound, 
Gertrude Stein, “as rimas de Marianne Moore”, João Cabral e as seleções cromáticas de Paul Klee, por exemplo, apontam para uma poética crítica que elege procedimentos técnicos determinantes de um modo de compor que valoriza a materialidade, a crítica da realidade e as fraturas das construções verbais.

O eu lírico perde a noção de referencialidade num mundo invadido pelos simulacros produzidos pelos meios de comunicação de massa, refugiando-se numa constante dúvida a respeito das fronteiras entre a realidade e a imaginação, bem como da possibilidade de qualquer explicação plausível sobre o real. Tal desreferencialização se torna visível pela utilização do fait divers, como se lê em "Limpeza":

250 mil mortos após

Sarajevo

Volta a respirar

Onde está Radovan Karadzic?

Os espectros rondam

As minas terrestres

Seis milhões

O que pode a Anphibia?

Serão décadas

Entre as ruínas

Um jovem de cócoras lê o jornal.*

O poema revela forte lastro político, ao mostrar a precariedade de um mundo após a destruição da guerra dos Bálcãs, no entanto a referencialidade do poema é o simulacro construído pelos media. Consumidor contumaz de notícias de jornais, Uchoa Leite muitas vezes utiliza a técnica de redação, que, em razão de sua objetividade, retira da escrita a carga de dramaticidade e sentimentalismo. Outro exemplo desse recurso pode ser visto no poema "Cortes/toques":

Van Gogh cortou a orelha

O Pequeno Hans tinha pânico de cavalos

Landru queimava mulheres

Manson \& Família

Riscaram Pig com o sangue das vítimas

No subúrbio do Rio acharam

Mulher tapada numa cisterna

Papéis jornais recortes

Grandes entulhos e um canal

É difícil entender a desordem
" (Leite, Sebastião Uchoa. "Limpeza". Em: A espreita. São Paulo: Perspectiva, 2000: 69). 
" (Leite, Sebastião Uchoa. "Cortes/toques". Em: Obras em dobras (1960-1988). Ob. cit.: 17).
Há um ano ela olhava o mar desta janela

Nefesh Nafs Atman

Que quer dizer alma?

Bombons envenenados no Japão

Parece a corcunda do Kierkegaard

Um toque de dedos rápido

O prazer de alfinetes

Aqui é o limite: atenção

Como punctum de uma foto

A orelha cortada é uma sinédoque.*

Num movimento caleidoscópico, o poeta dispõe episódios no mesmo plano de percepções, provocando um mosaico de citações e uma enumeração caótica de dados retirados de notícias de jornal que relatam tragédias de assassinatos históricos, combinados a desesperos particulares e anônimos, suicídios reais acontecidos em vários países. As referências que aparecem no poema coexistem e interagem como partes de um sistema, sem que se estabeleça qualquer grau de hierarquização entre elas. Os fragmentos de textos confluem entre si no mesmo espaço poético, diluindo a noção de historicidade.

As colagens de pensamentos e frases não obedecem a um discurso lógico, mas absorvem, no mesmo espaço, personagens reais e ficcionais, a exemplo do protagonista Hans Castorp, de A montanha mágica, de Thomas Mann. Ao trazer referências ao estilo de manchetes de jornais sensacionalistas, o poema relata os fatos com distanciamento e objetividade, evitando qualquer relação subjetiva com o conteúdo narrado.

O poema utiliza a técnica eisensteiniana de cortes e montagens. O olhar fotográfico vai clicando flashes, com um "toque de dedos rápido", e cristalizando, via escrita, fragmentos de cenas hediondas do real. O centro de interesse do poeta é o punctum, para lembrar também Roland Barthes, não na totalidade, sinalizando a impossibilidade de interpretá-los de modo universalista. Em grande parte da produção de Uchoa Leite, o que mais lhe "punge" são os detalhes metonímicos de cenas recortadas de fatos reais.

Consciente de que a análise e a interpretação dos fatos é limitada pela linguagem, cabe ao sujeito apreendê-los apenas como sinédoque. Os vários punctuns rearranjados no poema, como a orelha cortada de Van Gogh, ao lado de detalhes retirados de crimes famosos como os de Landru e Charles Manson, 
ou o envenenamento de balas no Japão, são sinédoques do lado obscuro e pouco decifrável da violência inerente ao ser humano. Tudo é linguagem. Porque tudo está povoado de signos. A orelha de Van Gogh e os demais fragmentos de fatos reais são sinédoques dos distúrbios humanos, às vezes inexplicáveis, dentro da história e do cotidiano. A mesma perplexidade encontra-se também em "Faits Divers/1980":

ler o capital

ficou cada vez mais difícil

o mundo está girando ao contrário

o pensamento enlouqueceu

ou enlouqueceram o jornal

não se pode mais

acreditar nos crimes

nem nos assassinos ${ }^{*}$

O poema é uma referência ao crime cometido por Louis Althusser, em novembro de 1980, quando o filósofo francês, num acesso de loucura estrangulou sua esposa Hélène Rhytmann. Discute como todo discurso traz em si uma face oculta, distanciando-se da verdade como adequação. A metáfora do cubo se encaixa dentro dessa concepção de verdade, pois toda a visibilidade esconde o não visível.

Tornou-se difícil acreditar numa análise marxista e totalizante da sociedade, ironiza o poeta, ao expressar sua perplexidade diante dos acontecimentos que envolveram o filósofo francês. Autor de Ler o capital [Lire le capital], publicado em 1965, Althusser se dedicou à renovação da leitura de Marx, promovendo uma crítica de esquerda ao stalinismo. A loucura de um dos principais intérpretes do marxismo necessariamente contamina uma das vertentes do pensamento marxista na contemporaneidade, funcionando também como sinédoque de um mundo, cuja característica é a impossibilidade de sobrevivência de verdades universais e definitivas.

$\mathrm{O}$ poema sugere que as categorias fundamentais do marxismo não dão conta das formas sociais da atualidade, nem tampouco da complexidade da natureza humana. Fait divers, como explica Nizia Villaça, é “o dejeto inorganizado das notícias informes”*, ou seja, uma espécie de classificação do inclassificável, cuja existência só tem início lá onde o mundo cessa de ser nomeado e submetido a um catálogo conhecido (política, economia, sociedade, ciência). A sucessão de fatos insólitos e
"(: 92).

" (Villaça, Nízia. Paradoxos do pós-moderno: sujeito \& ficção. Rio de Janeiro: Ed. UFRJ, 1996). 
" (Leite, Sebastião Uchoa.

"Crimes paralelos e textos". Em: Obras em dobras (1960. 1988). Ob. cit.: 83). as notícias chocantes que vemos nos noticiários se misturam a fatos insignificantes, anônimos, que classificamos no jornal sob a rubrica de variedades.

O poema abaixo, "Crimes paralelos e textos”, de Isso não é aquilo, também traz as marcas da escrita dos faits divers, justapondo fatos reais de épocas distantes, a partir do famoso caso de Pierre Rivière:

em 1836 frança

o chamado pierre rivière

degolou mãe irmã e irmão menor

os saberes institucionais

entraram em contradição

140 anos depois um filósofo

descobriu o tex to assassinato

um crime explicado pelo texto

um texto explicado pelo crime

em 1980 méier

jovem médica liquidou a tiros

pai irmã menor e matou-se

tiro no ouvido

o revólver cabo madrepérola

fora fabricado pelo pai

não deixou explicações

não houve mais notícias

mas o crime não deixa de ser um texto*.

O crime ganhou notoriedade 140 anos depois, após ter sido analisado por Michel Foucault e colaboradores na obra $E u$, Pierre Riviére degolei minha mãe, minha irmã e meu irmão... Um caso de parricídio no século XIX. Daí o verso "um crime explicado pelo texto". A segunda estrofe retoma outro crime, igualmente hediondo, não mais na França, mas na periferia do Rio de Janeiro, promovendo a proximidade do real pelo tempo histórico da escrita. A incorporação do estilo conciso e objetivo do jornalismo reforça a alusão à página de jornal, mosaico em que fatos e fotos dividem espaço com notícias políticas, culturais, econômicas, entrecruzando-se e, quase sempre, contaminando-se.

Os fatos relatados no poema transcendem o espaço da realidade e passam a ser vistos no quadro da linguagem, ou seja, uma combinatória de signos dentro da cultura. A tragédia é banalizada e transformada em textualidade: "um crime explicado 
pelo texto”. Por outro viés, a transgressão de textos também é uma violência à pureza e à autonomia do texto literário: "um texto explicado pelo crime”.

Perplexo e impotente diante do real, resta ao eu lírico registrar o eterno retorno, a repetição da história do homem, como linguagem e objeto da cultura, inserido dentro de um sistema de analogias. Se tudo é linguagem, o mundo é um grande texto, rede de significantes tecidos com infinitas combinatórias de signos, cabendo ao poeta conceber analogias e correspondências entre o mundo - grande poema - e o poema um mundo -, para que cada verso abra um leque de relações em que se interpenetrem outros versos, outros poemas, outras linguagens, outros sentidos, enfim.

Um conciso levantamento da linguagem do livro $A$ uma incógnita* demonstra como Uchoa Leite realiza uma simbiose de discursos, em que se entrecruzam alusões a obras de arte e citações de autores consagrados da tradição moderna, como Kafka (“minha culpa não é a de Joseph K”), Emily Dickinson (“Tal Emily Dickinson/ dura e pura”); Samuel Beckett, Rilke, Nietzsche, Hammett, Lovercraft; Manuel Bandeira, João Cabral, Murilo Mendes ("Pensei: ótimo para um poema de Murilo Mendes sobre a ordem e a desordem”); a pintores (Man Ray) ou a quadros famosos, à semelhança das alusões que faz à "terceira figura" de A parábola dos cegos e a O país de Cocanha, de Peter Bruegel; a personagens literários, como Herr Doktor, e de histórias em quadrinhos, como Elektra Assassina, Watchmen, MAD. Há também referências a atrizes de cinema, Charlotte Rampling, a criminosos que se tornaram célebres ("meus crimes não são de Landru"), a detetives como Dick Tracy, além da presença do mundo da música erudita (Variações Goldberg, Der Tod und das Madchen) e de compositores: César Franck, Schubert, Thelonius Monk. Todo esse mosaico de referências operadas simultaneamente é produto da recusa da idéia do "grande divisor", resultando num texto impuro.

A cultura de massa funciona como contraponto no interior de uma estrutura que é herdeira das vanguardas e da alta cultura. Trata-se de uma poesia que se localiza num entre-lugar, situado entre a tradição da modernidade, das vanguardas, e as produções culturais da contemporaneidade.

O comentário feito por Raul Antelo sobre poetas contemporâneos que figuram na antologia Desencontrários, publicada em 1995 - Nelson Acher, Haroldo de Campos, Duda Machado, 
"(Antelo, Raúl. "A fala do fora: uma lida". Em: Ascher, Nelson e outros. Desencontrários. Curitiba: Associação Cultural Aveli. no Vieira, 1995: 11-17).
Josely Viana Baptista e Paulo Leminski-, acomoda-se, de certa forma, à poesia de Uchoa Leite. Respeitando as diferenças e singularidades óbvias desses poetas, o que os une é o traço de estar "desgeograficado", "desenraizado", produzindo um "discurso nômade".

Tais poetas se posicionam, como se estivessem em permanente estado de transição: envolvem-se com o objeto e deixam-se envolver por ele, sintetizando na sua escrita discursos díspares, de tal forma que se torna difícil depreender de seus textos uma matriz estética que fundamente o conjunto de suas obras, a exemplo de personalidades poéticas marcantes, como João Cabral, Drummond, Bandeira e outros modernistas:

Os poetas desencontrários sentem-se atraídos pela linguagem do fora, desaforo não ligado a uma presença, mas à ausência de uma ausência. Um tal discurso nômade procura um espaço onde o novo venha a ser outro. [...] Desenraizados, para eles, e conforme a melhor tradição pau-brasil, o sujeito lírico é um passante arlequinal e hermafrodita sem referências fixas e, portanto, desgeograficado, como herói-sem-caráter, fundindo nele próprio o espírito dos lugares que atravessa. Trata-se de um ser que passa por relações... flexões ou simples pré-posições de sua fala. [...] Seu lugar é o entre. Sua celebração, o entrudo. A estratégia oblíqua.*

A escrita do entre-lugar - que implica, a um só tempo, as idéias de limite e ambivalência - insere o poeta numa tendência muito freqüente na produção literária brasileira contemporânea. A experiência de Uchoa Leite situa-se na fronteira entre um princípio racional de composição, cujo estoque de artifícios torna a linguagem auto-referente, e um arsenal de procedimentos prosaicos, ligados a situações da realidade exterior: entre a autonomia da arte e as referências ao universo cotidiano e autobiográfico, entre a alta cultura e a cultura de massa, entre o tex to e o contex to, entre o real e o imaginário, entre a invenção com a linguagem e o engajamento com a realidade.

Outras premissas importantes para a arte modernista, como o apagamento da subjetividade e da voz autoral, também sofrem abalos em sua poesia. Embora tais procedimentos não sejam norteadores de sua obra, não têm importância secundária. Uchoa Leite não pretende deslocar o centro para a periferia, ou a periferia para o centro, mas sim promover uma rearticulação entre tais elementos, de modo que seu texto poético vá se 
construindo numa espécie de intervalo, algo que configura uma estética de transição simultaneamente parasitária e tributária da modernista.

Eticamente engajado com a crítica da realidade, o tex to de Uchoa Leite dialoga com as incertezas da sociedade contemporânea, focalizando a vida cotidiana como um exercício de sobrevivência em face da degradação social. Compagnon observa que, desde o início da Guerra Fria, só é possível representar o futuro sob a forma de catástrofe, e, dentro desse raciocínio, questiona: "a consciência pós-moderna não é, antes de tudo, o fim da fé no futuro?”* O futuro, para o homem pós-1950, é visto como uma incógnita. Diante das adversidades cotidianas, a preocupação com a própria sobrevivência passa a ser um traço proeminente: crise energética, medo de uma Terceira Guerra Mundial, guerra biológica e bomba nuclear são alguns dos temores que produzem a letargia do sujeito.

Na poesia de Uchoa Leite, a sensação de vertigem ("o abismo atrai a vertigem”) é ampliada para além das possibilidades de resolução humana, como se vê em "Consciência de bolha":

Estamos propensos

Ao Princípio de Incerteza

Esmaga-nos

A goela do Big Crunch

Em que Não-localidade

Nos achamos?

Perplexos

Vamos todos desconexos

Nesse roldão universal*

O poema tece uma reflexão sobre a insegurança do homem diante das contingências do mundo contemporâneo. Como expressa o título, a sensação é de habitar numa bolha prestes a explodir (a imagem da bolha pode ser lida como protetora isolante do sujeito do mundo exterior). O desconforto de habitar em um não-lugar, num universo ameaçado de ruir, aumenta a incerteza do eu, que se encontra à mercê das contingências e se revela perplexo diante da impossibilidade de reação: "Vamos todos desconexos / Nesse roldão universal”. Tal perplexidade confere ao eu uma sensação de estar assujeitado, enfraquecido e sitiado.

Se a iminência de uma guerra nuclear ou catástrofe ecológica é uma constante ameaça à permanência da vida no planeta, o
" (Compagnon, Antoine. Os cinco paradoxos da mo dernidade. Ob. cit: 113).

" (Leite, Sebastião Uchoa. "Consciência de bolha". Em: A uma incógnita. Ob. cit: 28). 
poema amplia esse problema para além das possibilidades de resolução, mostrando que estamos todos propensos ao "Princípio da Incerteza", segundo a teoria formulada por Heisenberg.

De acordo com tal princípio, é impossível prever acontecimentos futuros, uma vez que não é possível medir com precisão o estado do Universo. A mecânica quântica prevê vários resultados possíveis para uma observação, o que quer dizer que há várias probabilidades para cada um dos futuros possíveis do mundo. A metáfora do Big Crunch também está relacionada a teorias da física contemporânea. Os cientistas que estudam esse fenômeno afirmam que, teoricamente, o universo está em incessante expansão, mas que ele é finito. Se o universo continuar se expandindo, chegará num determinado limite e passará, portanto, a reunir toda sua matéria de volta. Vejamos o poema "Fragmentos cósmicos":

Todo sistema tende

A um grau crescente de desordem

Onde depositar

O lixo cósmico?

Informação é matéria-prima

A paciência é elástica

Inflar bem lento e explodir

Como no Big Bang*

A teoria da expansão constante do universo, que se depara com seu limite, obrigando-o a se contrair, permite-nos fazer uma conexão com o universo da arte e da literatura. Se for restrito o número de combinações e se os estilos mais singulares já foram concebidos e experimentados, atingindo alto grau de radicalização, a arte também entra num processo de compressão, compelindo-a a um retraimento. Daí que a revisitação do passado, a busca da tradição, é uma das táticas encontradas como alternativa ao beco sem saída. 
Doutor em Estudos Literários (UNESP/Araraquara) e professor de Teoria da Literatura e Literatura Brasileira e Portuguesa na Unicastelo. Autor de Torquato Neto: uma poética de estilhaços (São Paulo: Annablume/Fapesp, 2002) e de vários ensaios em livros e revistas especializadas nacionais e internacionais.

\section{Resumo}

A obra de Sebastião Uchoa Leite é circunscrita num campo de tensão desvio e aproximação - com a tradição, o que impossibilita a demarcação de limites a quem busca traçar um contorno da sua poética. A inegável identificação com os mestres modernistas não significa a ampliação de tais modelos; ao contrário, estes são contaminados pelo entrecruzamento das mais diversas referências. A indecidível ambigüidade decorre do fato de que o poeta não demarca nenhum território espaciotemporal, nem norteia direções definidas. Trata-se de um projeto textual híbrido, de travessia, cujo percurso nômade faz transitar, lado a lado, discursos referenciais da tradição e do mundo contemporâneo.

\section{Abstract}

Sebastião Uchoa Leite's work is circumscribed in a field of tension with tradition, which weakens the boundary of limits to whoever seeks to go through a shape of his poetic. The undeniable identification with the modernist masters does not mean the enlargement of such standards; on the contrary, they are contaminated by the crossing of the most diverse references. The ambiguity comes from the fact that the poet does not put limits in a temporal-spaced territory, nor set defined directions. It is about a hybrid textual project, a crossing one, which the nomad route makes it go through, side by side, the referring speeches of tradition and the contemporary world.

\section{Resumén}

La obra de Sebastião Uchoa Leite es circunscripta en un campo de tensión-desvío y aproximacióncon la tradición, lo que impide la demarcación de límites a quién busca trazar un contorno de su poética. La innegable identificación con los maestreo modernistas no significa la ampliación de dichos modelos, por el contrario, estos son contaminados por el entrecruce de referencias de las más diversas. La indecible ambigüedad resulta del hecho de que el poeta no demarca ningún territorio espacio-temporal, ni nortea direcciones definidas. Se trata de un proyecto textual híbrido, de travesía, cuyo transcurso nómada hace transitar, lado a lado, discursos referenciales de la tradición y del mundo contemporáneo.
Palavras-chave

Sebastião Uchoa Leite poesia contemporânea modernidade estética

Key words

Sebastião Uchoa Leite contemporary poetry aesthetics modernity

Palabras-Ilave

Sebastião Uchoa Leite poesía contemporánea modernidad estética.

Recebido em 30/09/2005

Aprovado em 23/12/2005 